\title{
A novel grading methodology and recovery assessment technique for dimensional stone production
}

\author{
A Rajan Babu, GC Naveen and SS Meena \\ Centre for Testing Services ( ${ }^{1}$ formerly) \\ National Institute of Rock Mechanics \\ Kolar Gold Fields, Karnataka, India \\ ddstrajan@gmail.com
}

\begin{abstract}
A methodology was formulated for grading the quarries. To grade the quarry in terms of quality, the geological-cum-geotechnical characteristics of the rock mass and physico-mechanical properties were mainly considered. The point load test and rebound hardness using Schmidt hammer were used to estimate the in-situ uniaxial strength of the rock mass. Representative blocks of samples were taken from each quarry for laboratory studies to determine their critical properties as dimensional stone. The grading guidelines for recoverable volume are as Grade - A Blocks of Uniform Colour and without defects, Grade - B Blocks with uniform colour and $<\mathbf{1 0 \%}$ natural defects $/ \mathrm{m} 3$, Grade - C Blocks with distributed colour with $11 \%-30 \%$ natural defects $/ \mathrm{m} 3$ and Grade - D Blocks with distributed colour and $>\mathbf{3 0} \%$ natural defects $/ \mathrm{m} 3$
\end{abstract}

Case studies were taken up in four different dimensional stone granite quarries. The quarries were initially assessed for their overall recovery and from the estimated recovery, the percentage of various grades were projected. Based on the grading principle, the overall recovery is found to be $16 \%(\mathrm{~A}$ $12 \%$, B-32\%, C-38\%, D-19\%), 18\% (A-4\%, B-25\%, C-41\%, $\mathrm{D}-30 \%), 26 \%(\mathrm{~A}-5 \%, \mathrm{~B}-39 \%, \mathrm{C}-32 \%, \mathrm{D}-24 \%)$ and $21 \%$ (A$4 \%, \mathrm{~B}-39 \%, \mathrm{C}-33 \%, \mathrm{D}-24 \%)$ respectively. The projected recoveries and grading can be adopted at $90 \%$ confidence level.

Keywords_-grading; dimensional stone; recovery

\section{INTRODUCTION}

The continuation of a quarry and hence the profitability of block production is mainly controlled by the recovery of saleable or marketable volume. The rock mass by its nature is bound to exist with several geological weak planes and other material defects imposing restrictions on investments for full pledged quarry operations. However, a few rare deposits provide a relatively more recoverable volume leading to profitable operations. In India, several quarries are actively engaged in producing dimensional blocks contributing to about $25 \%$ of revenue generation from foreign exchange. On a whole, irrespective of the method of extraction including the modern techniques, about $85 \%$ of the quarries are facing problems with discouraging recoveries leading to abandoning of the operations quite frequently. The quarrying of dimension stone is one of the most exacting processes in the extraction industries. A major problem is the inability to predict the jointing, bedding plane, and fault systems, which control block layout on a given bench. An unanticipated joint or fault may upset the most careful planning for block layout. Another major problem is the need to divide blocks to required dimension without creating microscopic fractures in the quarried stone. Such cracks can cause the loss of finished product. More importantly the natural defects present in the rockmass play a vital role in deciding the recovery of quality blocks and hence the profitability of operations.

\section{CRITICAL PARAMETERS FOR BLOCK EXTRACTION}

Number of case studies has been conducted by the authors solving various problems associated with the exploitation of granite blocks. Data generated during the studies has been recorded and critically assessed with respect to their response to various aspects of block extraction. All parameters influencing the extraction of blocks have been considered to define the critical parameters that control the production of saleable blocks. Certain parameters are to be simultaneously compensated during the block extraction process. These parameters may be called as the critical parameter, which prevails on the decision for opting of a quarry for extraction. The critical parameters are shown in fig. 1.

\section{A. Mode of Occurrence of the Deposit}

Once the commercial validity of the stone has been proved, the next operation will be to open the quarry to make it amenable for block production. Opening up of a quarry at the right location with sufficient provision for development of working faces, haul roads, expansion of benches etc., is an important process in the quarrying for dimensional stones. The location and methods of opening up depends mainly on topography of the area. A major problem of Indian quarries are that most of the quarries (of any topography) were not developed in a systematic way and very frequently either needs to be abandoned or reopened from a different location. Abandoning or reopening of a quarry involves huge losses/investments and often discourage/curtail further advancements due to shortage of working capital. 


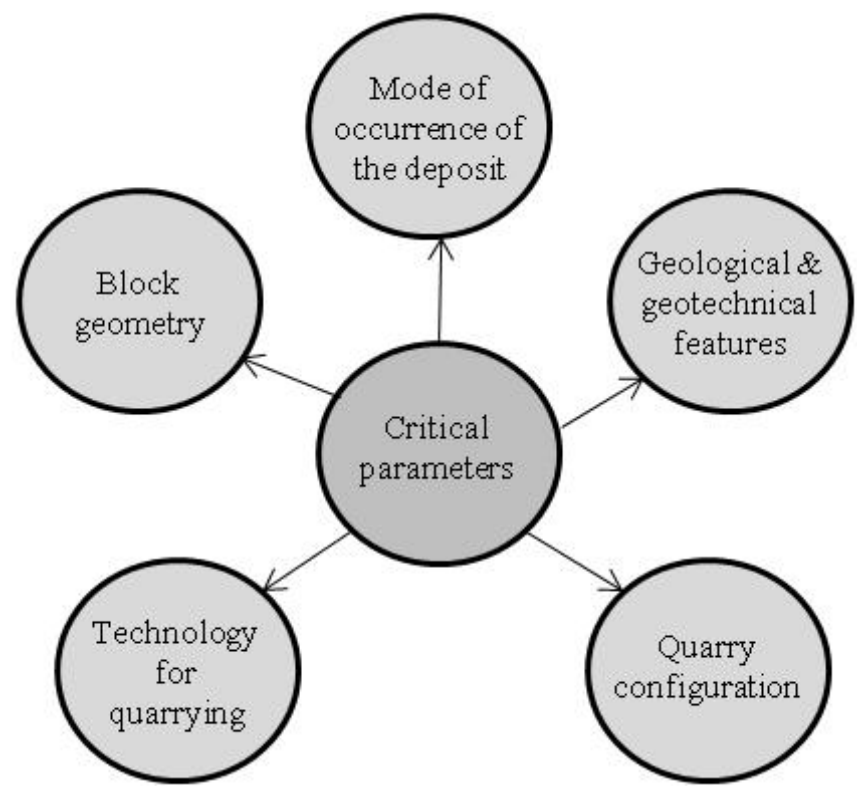

Fig. 1. Critical parameters for stone quarrying

\section{B. Geological-cum-Geotechnical Characteristics}

The block splitting technique for a site largely depends on the physico-mechanical properties of the rock and the nature $\&$ orientation of the jointing system. Splitting becomes easy when prominent loose joints are present in vertical and horizontal planes. Loose or filled joints are very rarely encountered and only tight joints are commonly present. The prevailing conditions at the field overwhelmingly demand meticulous planning for safe extraction and preservation of the valuable blocks. Quite often the need for drilling required number of holes were neglected without considering the nature of the jointing system (loose/tight). There is a wrong apprehension to save on drilling that finally ends up with damage to the saleable blocks. It is upheld not to compromise on drilling the required number of holes at correct spacing for both vertical and horizontal splitting. Before a decision could be made it is prudent to thoroughly inspect the jointing patterns and confirm its nature. The following properties shall be studied to assess the quality of stone for their commercial viability.

i. Structure, Texture

ii. Color, Intrinsic designs etc.,

iii. Discontinuities, Fractures, Joints

iv. Bedding planes etc.,

v. Physico-mechanical properties of the rock

\section{Quarry Configuration}

The orientation of faces significantly influences the recovery of saleable blocks. The orientation of faces in favorable direction, usually along the strike of the foliation or the major joint set is desired. Unfavorable orientations very frequently result in damage to the rock mass and wastage of valuable material through development/propagation of cracks/fractures and toe formations. Sometimes it becomes compulsory to orient the faces across the foliation to produce block patterns most liked by the buyers. In such cases; a matching technology should be adopted to combat any adverse affect arising out of unfavorable face orientation. The following parameters largely govern the quarry configuration.

- Dimensions of the quarry

- Number of quarry-faces

- Orientation of faces and direction of advance

\section{Technology for quarrying}

The rock mass response to various techniques of extraction is seldom considered during the process of machinery selection that has a vital role to play in the economics of operation. Unlike other mining operations, the quarrying of granite demands for site-specific selection of machineries owing to large variations in their geological, geotechnical and physico mechanical characteristics. A successful extraction technology in one quarry may not yield good results in another quarry. The huge investments made on these machineries are difficult to be realized immediately due to mismatching of equipment with the production. Under similar conditions of mining, the quarries producing granite type having superior commercial value can afford to invest on the machineries with ease compared to the other granite types having inferior market value. The fluctuations in the market values of different varieties of granite would also significantly influence the choice for the degree of mechanization. Therefore, the selection of a proper technique of extraction is an elegant task.

\section{E. Block geometry}

Determination of block geometry and hence the correct block size is critical in the extraction process. Detailed geotechnical mapping must be conducted on the area identified to record the strike, dip of foliation, joints etc. Visible cracks and material defects such as black patches, moles, quartz veins etc. shall be recorded.

The theoretical volume and volume estimated by projections of joints, visible material defects etc., should be compared for varying bench geometry. The ultimate objective of any stone operator is to produce good quality blocks at optimum cost with maximum recovery. To achieve the above objective, it is very important to choose a suitable technique of extraction as it has a high bearing on the desired results. Unfortunately, in India, not many operators are exposed to scientific way of quarrying though they have awareness of widely used quarrying techniques.

\section{RISK ASSOCIATED WITH VARIOUS QUARRY ACTIVITIES}

Considering the critical parameters, performance evaluation of available extraction technologies and applicability of different techniques for various nature of deposit, the most important activities of the quarry were derived. The various activities are listed in Table I and ratings are given on a scale of $0-10$ in the increasing order of influence from lowest to highest.

The ratings are based on qualitative assessment and were arrived at after carefully studying their influence in several quarries. The ratings suggested would be useful for the 
entrepreneurs in meticulous planning \& scheduling of various quarrying activities. Thus, the risk of wrong investments can be minimised to a great extent.

TABLE I. DEGREE OF INFLUENCE OF VARIOUS ACTIVITIES ON GRANITE EXPLOITATION

\begin{tabular}{|l|l|l|}
\hline \multicolumn{1}{|c|}{ Parameters } & \multicolumn{1}{|c|}{ Application } & Rating \\
\hline $\begin{array}{l}\text { Topographic } \\
\text { survey }\end{array}$ & Location of the quarry & 5 \\
\hline $\begin{array}{l}\text { Geological } \\
\text { investigation }\end{array}$ & $\begin{array}{l}\text { Assessment of rock quality and } \\
\text { quantity with respect to commercial } \\
\text { viability }\end{array}$ & 10 \\
\hline $\begin{array}{l}\text { Geotechnical } \\
\text { investigation }\end{array}$ & $\begin{array}{l}\text { Estimation of recovery of saleable } \\
\text { blocks in terms of volume, shape and } \\
\text { size }\end{array}$ & 8 \\
\hline Quarry lay out & $\begin{array}{l}\text { Design of approach roads, block } \\
\text { geometry, etc }\end{array}$ & 7 \\
\hline $\begin{array}{l}\text { Quarrying } \\
\text { techniques }\end{array}$ & $\begin{array}{l}\text { Selection of suitable exploitation } \\
\text { technique(s) }\end{array}$ & 6 \\
\hline $\begin{array}{l}\text { Quarrying } \\
\text { machinery }\end{array}$ & $\begin{array}{l}\text { Selection of suitable machinery for } \\
\text { various activities of exploitation }\end{array}$ & 9 \\
\hline Production plan & $\begin{array}{l}\text { Design of number of benches, } \\
\text { production faces, etc }\end{array}$ & 5 \\
\hline Quarrying plan & Development/expansion schedules, & 4 \\
\hline $\begin{array}{l}\text { Environmental } \\
\text { plan }\end{array}$ & $\begin{array}{l}\text { Pollution control, waste management, } \\
\text { etc }\end{array}$ & 5 \\
\hline $\begin{array}{l}\text { Economic } \\
\text { analysis }\end{array}$ & Loss/profit assessment, & 10 \\
\hline & & \\
\hline
\end{tabular}

\section{RECOVERY}

The extraction of saleable blocks is one of the most critical processes in the quarrying of dimensional stones. The quarry operators are constantly under pressure to produce good quality and required quantity of saleable blocks to meet their production target and market demand. The continuation of a quarry and hence the profitability of block production is mainly controlled by the recovery of saleable or marketable volume.

In general irregular and continuous record of low recovery poses a serious threat to the continuance of the mining operations in most of the quarries. The scientific exploitation of the given deposit is a key for improving the recovery. The average recovery percentage world over by various authors is presented in Table II.

\section{A. Defects}

Some of the major defects which control the recovery of saleable blocks include;

i. Mole (segregation of darker minerals or inclusions).

ii. Flowers (concentration of quartz in black granite).

TABLE II. SHOWING THE VARIOUS RECOVERY PERCENTAGES WORLD OVER

\begin{tabular}{|l|l|}
\hline \multicolumn{1}{|c|}{ Authors/Agency } & \multicolumn{1}{c|}{ Recovery (\%) } \\
\hline Ashmole (2008) & $10-12$ \\
\hline IBM (2013) & $5-15$ \\
\hline Rajgor (2013) & $5-15$ \\
\hline Crackmite (2015) & 30 \\
\hline University of Tennesse (2006) & $7-97$ \\
\hline Other Studies & $22-85$ \\
\hline
\end{tabular}

iii. Green lines or streaks (due to alteration of pyroxene in to chlorite).

iv. Inclusion of secondary minerals (quartz, calcite, zeolite).

v. Pitted surface (due to removal of soft mica and platy minerals).

vi. Hairline cracks (due to natural! tectonic disturbances or blasting effects).

vii. Cracks at the contact of quartz veins with

ferromagnetism minerals (due to injection effects and differences in hardness).

viii. Occurrence of crystals of pyrite or marcasite.

The market demand sometimes provides a helping hand when it is on the high. However, frequent market fluctuations leads to uncertainties in the productions thereby the industry is always facing risk. Some of the defects commonly encountered are shown in figure $2 \mathrm{a}, 2 \mathrm{~b}, 2 \mathrm{c}, 2 \mathrm{~d}, 2 \mathrm{e}, 2 \mathrm{f}$ and $2 \mathrm{~g}$.

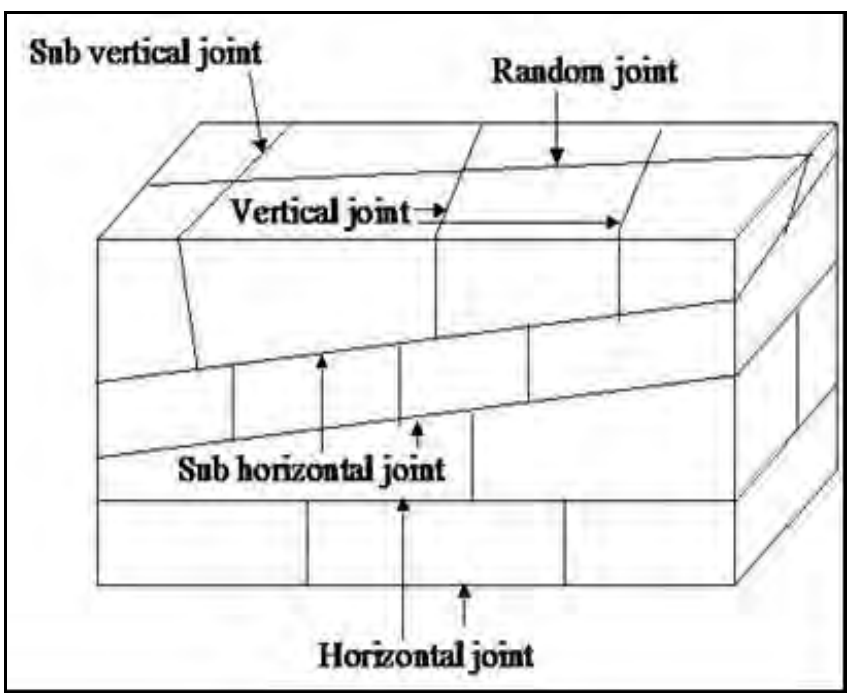

Fig.2a. The jointing pattern

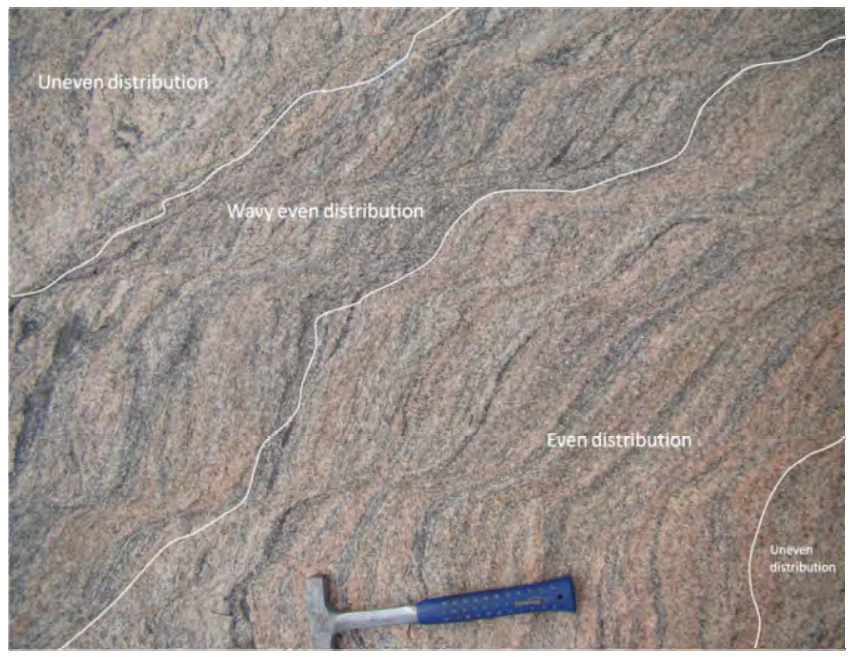

Fig. 2b. Uneven distribution of minerals 


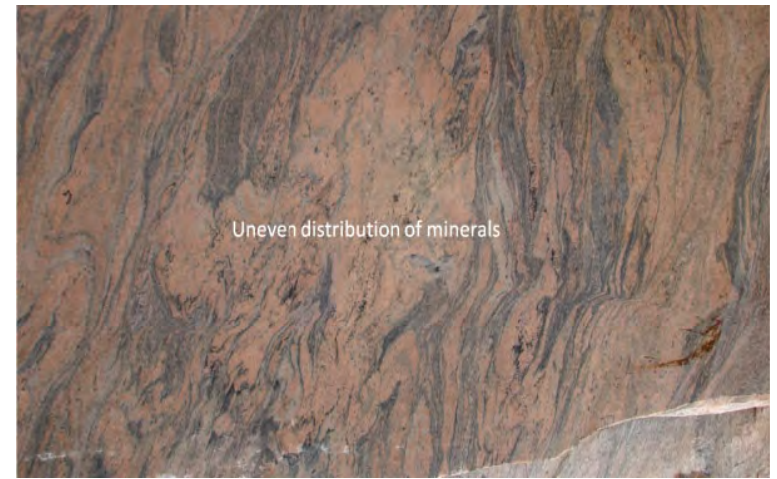

Fig. 2c. Uneven distribution of fine to medium grain minerals

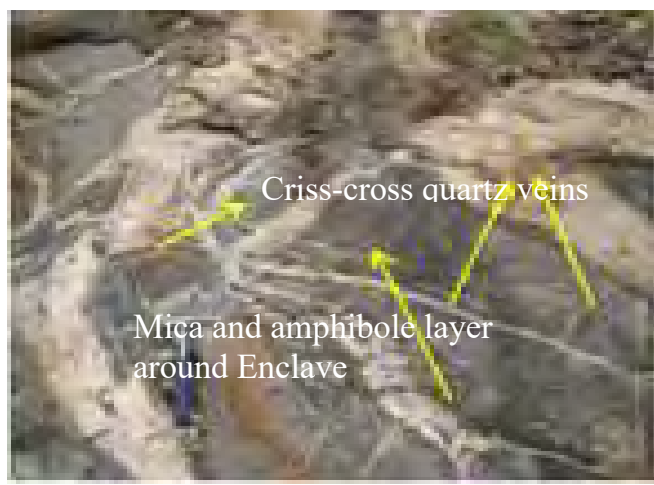

Fig. 2d. Criss - cross veins of quartz and pegmatite intruded into the Mafic Enclaves

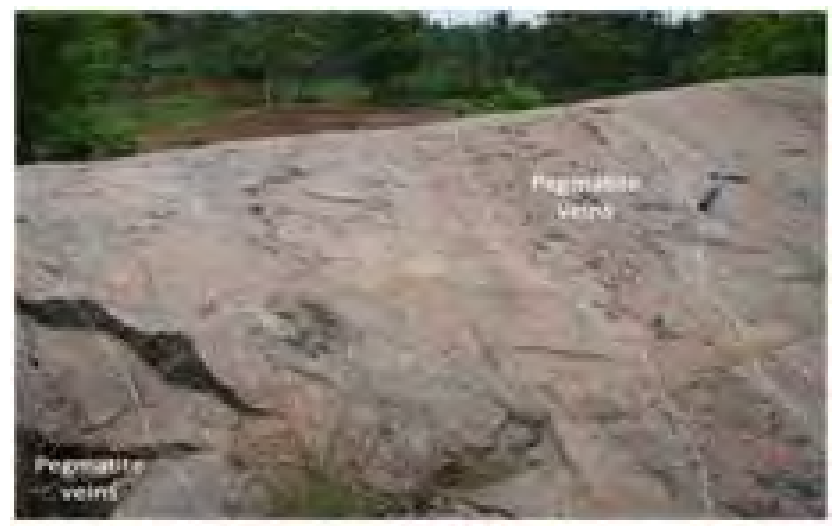

Fig. 2e. Pegmatite distribution

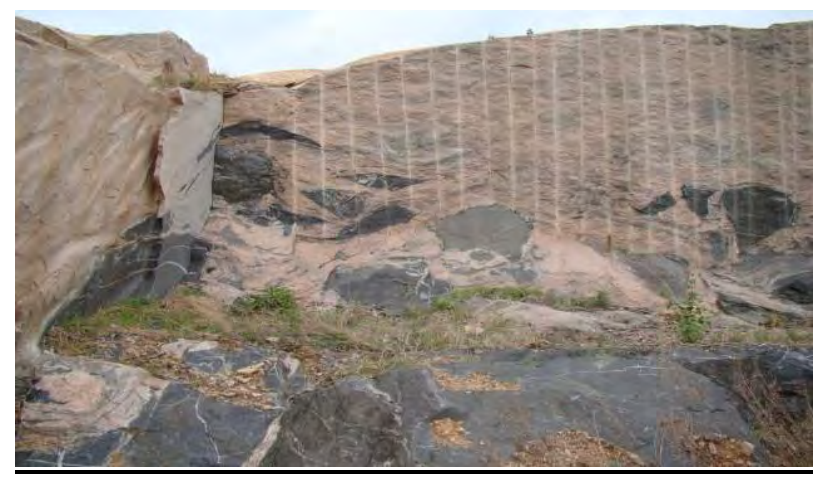

Fig. 2f. Enclaves found in full height of quarry face
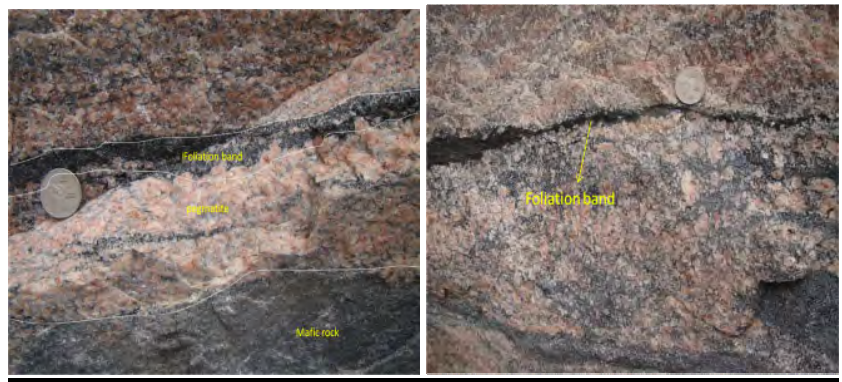

Fig. 2g. Foliation band, pegmatite intrusion and mafic rock

\section{CASE Studies on Recovery (After RAJAn BABU eT AL, 2011)}

Estimation of recoverable reserves involves evaluation of geotechnical aspects, volume, quality, size and shape of deposit. Structural mapping using scan line method was carried out to estimate the volume of recoverable blocks.

Surface observations related to structural features like strike \& dip of joints, lineation, folds and faults, variation in mineral component, variation in textural feature, variation in color, quartz veins, and amphibolites was observed in the deposit. Blocks of varying size was considered for reserve estimation; three dimensional block diagram was prepared for three blocks according to the scale of geological mapping where all the information is projected (figures $3 \mathrm{a}, 3 \mathrm{~b} \& 3 \mathrm{c}$ ).

The presence of natural defects like joints, faults, Zenoliths, foliation bands, pegmatites, color variation were considered for theoretical volume calculation. From theoretical volume, recoverable volume which includes natural defects like foliation bands, pegmatites, color variation etc. was estimated and the percentage varied from block to block. The theoretical volume and estimated recoveries were calculated as shown in the following Tables $3,4,5$ and 6 respectively for the four case studies.

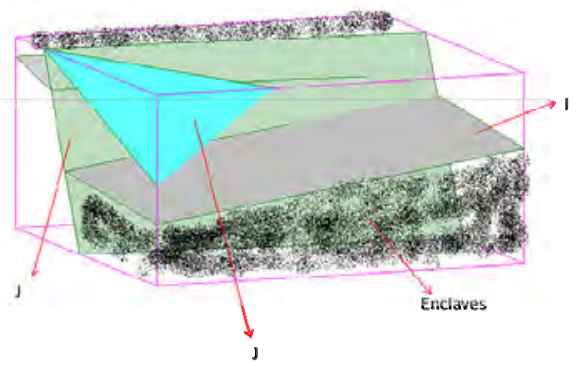

Fig. 3a. Three dimensional view of block-I

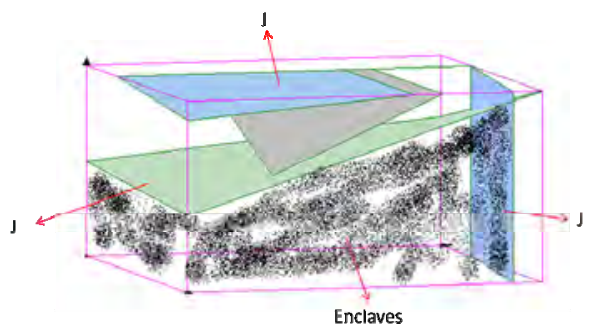

Fig. 3b. Three dimensional view of block-II 


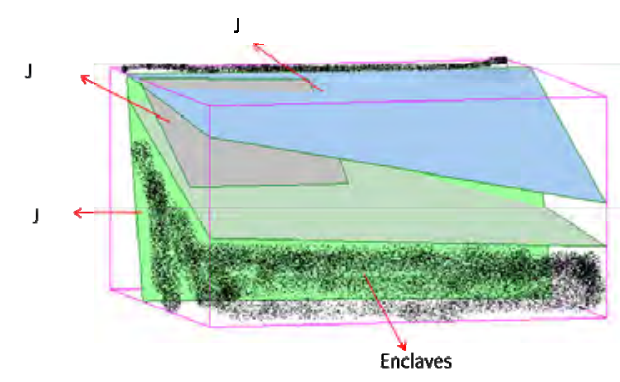

Fig.3c. Three dimensional view of block-III

\section{Estimation OF STRENGTH IN FIELD}

Durability is an important selection criterion for the dimensional stones. It is the time measure of the ability of dimension stone to endure and to maintain its essential and distinctive characteristics of strength. Schmidt hammer and Point load tester was used for measuring the rebound hardness of the strata and for estimation of indirect uniaxial compressive strength

TABLE III. CASE STUDY -I

\begin{tabular}{|c|c|c|c|c|}
\hline $\begin{array}{c}\text { SI } \\
\dot{\mathbf{N}} \\
\mathbf{0}\end{array}$ & $\begin{array}{c}\text { Block } \\
\text { size }\left(\mathbf{m}^{3}\right)\end{array}$ & $\begin{array}{l}\text { Theoretical } \\
\text { volume }\left(\mathbf{m}^{3}\right)\end{array}$ & $\begin{array}{c}\text { Estimated } \\
\text { recoverable } \\
\text { volume with } \\
\text { natural defects } \\
\left(\mathbf{m}^{3}\right)\end{array}$ & $\begin{array}{c}\text { Percentage } \\
(\%) \\
\text { (Estimated } \\
\text { recoverable } \\
\text { volume / } \\
\text { Theoretical } \\
\text { volume) } \\
\end{array}$ \\
\hline 1 & $25 * 20 * 5$ & 2500 & 440 & 17.6 \\
\hline 2 & $25 * 10 * 5$ & 1250 & 148 & 11.84 \\
\hline 3 & $25 * 20 * 5$ & 2500 & 488 & 19.52 \\
\hline \multicolumn{4}{|c|}{ Projected average recovery for the whole quarry $(\%)$} & 17.21 \\
\hline
\end{tabular}

TABLE IV. CASE STUDY - II

\begin{tabular}{|l|l|l|l|l|}
\hline $\begin{array}{c}\text { SI } \\
\text { No }\end{array}$ & $\begin{array}{c}\text { Block size } \\
\mathbf{( m 3 )}\end{array}$ & $\begin{array}{c}\text { Theoretical } \\
\text { volume }(\mathbf{m 3})\end{array}$ & $\begin{array}{c}\text { Estimated } \\
\text { recoverable } \\
\text { volume with } \\
\text { natural } \\
\text { defects }(\mathbf{m 3})\end{array}$ & $\begin{array}{c}\text { Percentage } \\
\text { (\%) } \\
\text { (Estimated } \\
\text { recoverable } \\
\text { volume / } \\
\text { Theoretical } \\
\text { volume) }\end{array}$ \\
\hline 1 & $10 * 8 * 8$ & 640 & 87 & 14 \\
\hline 2 & $8 * 8 * 7$ & 448 & 168 & 38 \\
\hline 3 & $10 * 16 * 10$ & 1600 & 215 & 13 \\
\hline 4 & $10 * 8 * 8$ & 640 & 45 & 7 \\
\hline \multicolumn{2}{|l}{ Projected average recovery for the whole quarry $(\%)$} & 18 \\
\hline
\end{tabular}

TABLE V. CASE STUDY - III

\begin{tabular}{|c|c|c|c|c|}
\hline $\begin{array}{l}\text { Sl. } \\
\text { No }\end{array}$ & $\begin{array}{l}\text { Block } \\
\text { size } \\
\left(\mathbf{m}^{3}\right)\end{array}$ & $\begin{array}{c}\text { Theoretica } \\
\text { l volume } \\
\left(\mathbf{m}^{3}\right)\end{array}$ & $\begin{array}{c}\text { Estimated } \\
\text { recoverable } \\
\text { volume with } \\
\text { natural } \\
\text { defects }\left(\mathbf{m}^{3}\right)\end{array}$ & $\begin{array}{c}\text { Percentage }(\%) \\
\text { (Estimated } \\
\text { recoverable volume / } \\
\text { Theoretical volume) }\end{array}$ \\
\hline 1 & $\begin{array}{l}6 * 3.3 \\
* 5\end{array}$ & 99 & 16 & 16 \\
\hline 2 & $\begin{array}{l}9 * 6 * \\
5.5\end{array}$ & 297 & 98 & 33 \\
\hline 3 & $\begin{array}{l}6 * 5.5 \\
* 5\end{array}$ & 165 & 50 & 30 \\
\hline \multicolumn{4}{|c|}{$\begin{array}{l}\text { Projected average recovery for the whole } \\
\text { quarry }(\%)\end{array}$} & 26 \\
\hline
\end{tabular}

TABLE VI. CASE STUDY -IV

\begin{tabular}{|c|c|c|c|c|}
\hline $\begin{array}{c}\text { Sl. } \\
\text { No. }\end{array}$ & $\begin{array}{c}\text { Block } \\
\text { size } \\
\left(\mathbf{m}^{\mathbf{3}}\right)\end{array}$ & $\begin{array}{c}\text { Theoretical } \\
\text { volume } \\
\left(\mathbf{m}^{3}\right)\end{array}$ & $\begin{array}{c}\text { Estimated } \\
\text { recoverable } \\
\text { volume with } \\
\text { natural defects } \\
\left(\mathbf{m}^{\mathbf{3}}\right)\end{array}$ & $\begin{array}{c}\text { Percentage } \\
\text { (\%) } \\
\text { (Estimated } \\
\text { recoverable } \\
\text { volume / } \\
\text { Theoretical } \\
\text { volume) }\end{array}$ \\
\hline 1 & $6 * 5 * 4$ & 120 & 21.6 & 18 \\
\hline 2 & $6 * 5 * 5$ & 150 & 24 & 16 \\
\hline 3 & $6 * 5 * 3$ & 90 & 27 & 30 \\
\hline \multicolumn{2}{|l|}{ Projected average recovery for the whole quarry (\%) } & 21 \\
\hline
\end{tabular}

Representative blocks of samples were taken from the quarry for laboratory studies to determine their uniaxial strength. Geological hammer was also used to estimate the strength whenever required.

\section{A. Point Load Testing}

Point load tester is one of the reliable methods to estimate compressive strength for irregular samples. The samples were collected randomly and tested for compressive strength. The estimated compressive strength of the collected samples ranged from $3 \mathrm{MPa}$ to $116 \mathrm{MPa}$. It was found that there was a difference in UCS between the parent rock and the enclaves. The UCS of parent rock was found to be $98 \mathrm{MPa}$ and in enclaves it was $116 \mathrm{MPa}$.

\section{B. Schmidt Hammer}

The Schmidt rebound hardness was measured with a view to estimate the in-situ uniaxial compressive strength (UCS). Schmidt hammer is one of the easy methods to estimate elastic properties or compressive strength of the rock. The hammer measures the rebound of a spring loaded mass impacting against the surface of the sample. Data was collected randomly along the exposed surface. A minimum of 20 measurements for rebound hardness was taken at each site. The top 10 readings were averaged to obtain the final readings.

Several empirical equations were available correlating the UCS and Schmidt rebound number. For this study the relation proposed by Yilmaz and Sendir (2002) was used. Accordingly, the UCS was estimated using the empirical equation: $\mathrm{UCS}=\exp (0.818+0.059 \mathrm{~N})$ with a correlation coefficient of 0.98 . It was found that there was a difference in UCS between the parent rock and the enclaves.

The UCS in this (close pet) rock type was found to be 58 $\mathrm{MPa}$ and in gabbro it as $93 \mathrm{MPa}$.

TABLE VII. DETERMINED PHYSICO-MECHANICAL PROPERTIES FOR

\begin{tabular}{|c|c|}
\hline \multicolumn{2}{|c|}{ ROCK } \\
\hline Property & Results \\
\hline Density, $\mathrm{kg} / \mathrm{m}^{3}$ & 2636 \\
\hline Bulk specific gravity & 2.66 \\
\hline Absorption, weight (\%) & 0.14 \\
\hline Porosity $(\%)$ & 0.38 \\
\hline P-wave velocity $(\mathrm{m} / \mathrm{s})$ & 4617 \\
\hline Compressive strength (MPa) & 201 \\
\hline Flexural strength $(\mathrm{MPa})$ & 7 \\
\hline Modulus of rupture (MPa) & 10 \\
\hline Abrasion resistance & 119 \\
\hline
\end{tabular}

C. Laboratory Testing 
Dimensional stone is evaluated for varying criteria, including its physico-mechanical properties like UCS, hardness, density, porosity etc. In order to determine the physico-mechanical properties, sample blocks from each quarry was identified and transported to the Rock Testing Laboratory at National Institute of Rock Mechanics (NIRM). All the tests were carried out as per the American Society for testing and materials (ASTM) and International Society of Rock Mechanics (ISRM) Standards. The determined physico-mechanical properties for the samples are given in Table 7.

Correlation of the physico-mechanical properties along with the intrinsic properties of the rock will help to evaluate their suitability as dimensional and decorative stones.

Absorption is high due to voids included in the rock i.e. microfractures and correlate closely with porosity. Uniaxial compressive strength, Flexural strength and P-wave velocity (VP) appear to decrease due to presence of linear crack. Modulus of rupture and abrasion resistance is quite low due to less compactness of grains.

\section{METHODOLOGY FOR GRADING}

With the background of geological, geotechnical characteristics and physico-mechanical properties, the following methodology was developed for grading the production of blocks in to different categories. The geological features or characteristics of a dimension stone can be divided into two main groupings: Visual or aesthetic features including colour, grain size, and textures and Technical features including petrography and mineralogy, brittle deformation, physical-mechanical properties, and available volumes.

Consistent visual or aesthetic features are of prime importance when evaluating the market potential of a stone. The technical features influence the performance of a stone and the choice of stone for uses (i.e.: indoor, outdoor, intense sunlight exposure, pollution, exposure to chemicals, grease, oil etc.). Higher technical ratings led to increased acceptance for various uses in the marketplace.

Note that although the physical-mechanical properties of a dimension stone are of prime important; it is the visual or aesthetic appearance and prestige of the stone (as dictated by the preferences of architects and designers) that drives the stones marketability for both residential and commercial usage.

Considering the above facts, the critical parameters which influence block quality was identified into two major groups. They are geological-cum-geotechnical parameters and the physico-mechanical characteristics of the rock material.

\section{A. Geological-cum-geotechnical parameters}

The structural features mainly covering occurrence and special distribution of joints plays a prominent role in deciding block ability from a deposit. The closely spaced joints (less than $1 \mathrm{~m}$ spacing) will not render gang saw or cutter size blocks.
Highly jointed rock mass conditions are not suitable for dimensional stone quarrying. However, owing to their aesthetic beauty and commercial importance certain variety of stones must be quarried under highly jointed conditions. The production of large size blocks is a remote possibility and only small blocks suitable for monuments are obtainable. Whatsoever the technique may be adopted for extraction, the wastage is envisaged on the higher side with very low recovery.

Natural defects such as moles, patches, veins, micro cracks, color variations, mineral composition etc and orientation of foliation planes are found to be prominent and influencing the recovery to a great deal. Therefore, joints, foliation planes and natural defects are assessed together for 'favorable' and 'unfavorable' conditions.

For grading the uniaxial compressive strength was considered as the main contributing parameter. The strength exceeding $100 \mathrm{MPa}$ was considered as hard rock and taken as favorable condition.

Finally, all the parameters in favorable conditions are integrated and projected their influence for $1 \mathrm{~m} 3$ of the block produced. The unfavorable condition is treated as waste or aggregate material.

Based on the percentage of defects envisaged in $1 \mathrm{~m} 3$ of block produced, the recoverable blocks are grouped in to the following grades (Table 8 and Figure 4).

TABLE VIII. GRADING OF RECOVERABLE BLOCKS

\begin{tabular}{|l|l|}
\hline \multicolumn{2}{|c|}{ Recoverable Blocks } \\
\hline $\begin{array}{l}\text { Grade }- \\
\text { A }\end{array}$ & Blocks of Uniform Colour and without defects \\
\hline $\begin{array}{l}\text { Grade }- \\
\text { B }\end{array}$ & $\begin{array}{l}\text { Blocks with uniform colour and }<10 \% \text { natural } \\
\text { defects } / \mathrm{m} 3\end{array}$ \\
\hline $\begin{array}{l}\text { Grade }- \\
\text { C }\end{array}$ & $\begin{array}{l}\text { Blocks with distributed colour with } 11 \%-30 \% \text { natural } \\
\text { defects } / \mathrm{m} 3\end{array}$ \\
\hline $\begin{array}{l}\text { Grade }- \\
\text { D }\end{array}$ & $\begin{array}{l}\text { Blocks with distributed colour and }>30 \% \text { natural } \\
\text { defects } / \mathrm{m} 3\end{array}$ \\
\hline
\end{tabular}

\section{B. Guidelines for Grading Measurement}

a) Make a template of $1 \times 1 \mathrm{~m}$ with a grid of $0.2 \times 0.2 \mathrm{~m}$ as shown in figure 5.

b) This template shall be used in all the three opposite faces of the block for locating and marking the defects such as moles, patches, bands, lines, stepped joints, colour varriation etc.

c) After marking the defects, the defect volume can be worked out preciously by counting the grids in the template and projecting the values in terms of percentages with respect to that block. The percentage defect is the average value obtained from all the three opposite faces. 


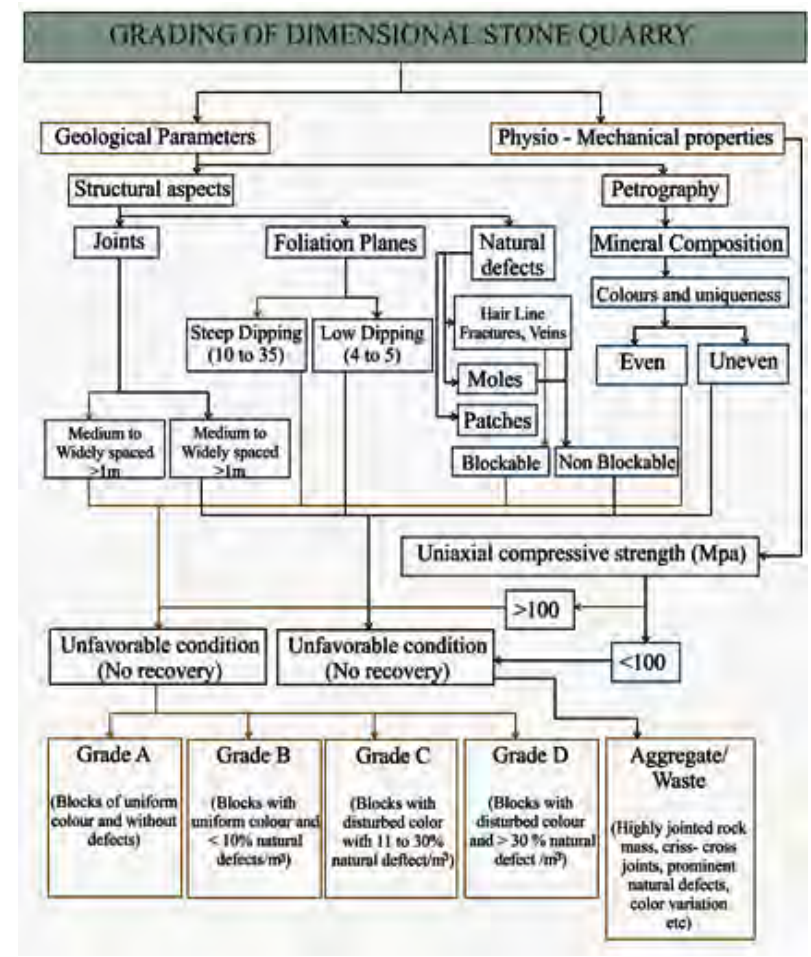

Fig.4. Flow Chart for Grading

\begin{tabular}{|c|c|c|c|c|c|c|}
\hline & \multicolumn{5}{|c|}{$1 \mathrm{~m}$} \\
\hline & & \multicolumn{5}{|c|}{$0.2 \mathrm{~m}$} \\
\hline \multirow{5}{*}{$\Xi$} & $\begin{array}{l}\mathbb{Z} \\
\text { Ny } \\
0\end{array}$ & 1 & 2 & 3 & 4 & 5 \\
\hline & & 6 & 7 & 8 & 9 & 10 \\
\hline & & 11 & 12 & 13 & 14 & 15 \\
\hline & & 16 & 17 & 18 & 19 & 20 \\
\hline & & 21 & 22 & 23 & 24 & 25 \\
\hline
\end{tabular}

Fig.5. Template for grading measurement

\section{CONCLUSIONS}

Lack of preliminary exploration and basic scientific studies for understanding the deposit is the cause for poor recovery and excessive waste generation in dimensional stone quarries. Critical parameters to produce saleable blocks were identified as the mode of occurrence, geological \&geotechnical characteristics, quarry configuration, quarrying technology and block geometry. A novel grading methodology is developed to forecast the percentage recovery of saleable blocks, first of its kind. This method is field tested and can be safely adopted at $90 \%$ confidence level. Geology of the deposit and its structural features along with physical and mechanical properties with an emphasis on the aesthetics of the cut surface of the stone was considered for the quality grading. The in-situ uniaxial strength of the rock mass was determined using point load test and rebound hardness using Schmidt hammer. The quarries were initially assessed for their overall recovery and from the estimated recovery, the percentage of various grades were projected. The quarries were categorized for overall recoveries and further graded into various grades as given below.

TABLE IX. GRADE PERCENTAGE

\begin{tabular}{|l|l|l|l|l|}
\hline Grade & $\begin{array}{c}\text { Case study - } \\
\text { I (16\%) }\end{array}$ & $\begin{array}{c}\text { Case study - } \\
\text { II (18\%) }\end{array}$ & $\begin{array}{c}\text { Case study - } \\
\text { III (26\%) }\end{array}$ & $\begin{array}{c}\text { Case study } \\
\text {-IV (21\%) }\end{array}$ \\
\hline A (\%) & 12 & 4 & 5 & 4 \\
\hline B (\%) & 32 & 25 & 39 & 39 \\
\hline C (\%) & 38 & 41 & 32 & 33 \\
\hline D (\%) & 19 & 30 & 24 & 24 \\
\hline
\end{tabular}

The grading methodology shall help the industry to minimize the disputes through a geotechnical baseline report including projected overall recoveries and sub-grading of the stone quality.

\section{REFERENCES}

[1] A.Rajan Babu and R.N. Gupta, "Site-characterisation for determination of the block geometry and splitting direction in granite stone quarrying," National seminar on rock fragmentation ROCKFRAG-01, Institute of Technology, Banaras Hindu University, Varanasi.

[2] A.Rajan Babu and R.N. Gupta, "Classification of granite quarries - a base for technology management," Journal of Mines, Metals \& Fuels, Aug-Sept, pp. 322-324,2001

[3] A. Rajan Babu, P. K. Behera and R. N. Gupta, "Influence of joints on block splitting - some logistic considerations," Proceedings, Dept. of Mines \& Geology, Stona, 2002.

[4] A. Rajan Babu, D.S. Subrahmanyam, J. Chattopadhyay, and R.N. Gupta, "Development of guidelines for improving recovery in granite mining operations,"Final report, 2002.

[5] A. Rajan Babu, P.K. Behera,and R N Gupta, "High performance quarrying of dimensional stones by optimisation through scientific methods", National seminar on recent development in machinery andequipment for dimensional stone mining, Udaipur, Rajasthan,December 2003.

[6] A. Rajan Babu,P.K. Behera, andR.N. Gupta, "Simplified guided procedure for block extraction in granite quarries," Seminar on natural construction materials: NATCON, Bangalore,March 2003.

[7] "Granite dimensional stone quarrying and processing: a critical study," Natural stone council, University of Tennesse, USA, 2006.

[8] Ashmole and Motloung, "Dimension stone: the latest trends in exploration and production technology," The South African instituteof of mining and metallurgy surface mining, 2008.

[9] A. Rajan Babu, and etal., "Grading of the Mysore Minerals Limited quarries at following locations: 1. Punjanur Black Granite QuarryChamrajnagar. 2. Mallainapura Black Granite QuarryChamrajnagar 3. Shivapura Black Granite Quarry-Chamrajnagar 4. Doddamudavadi Granite Quarry-Kanakapura, Ramnagar District,"Final report,2011.

[10] Rajgor,and J Pitroda,"Stone sludge: economical solution for manufacturing of bricks," International journal of innovative technology and exploring engineering (IJITEE) ISSN: 2278-3075,vol. 2(5), April 2013.

[11] Mineral Reviews -Part-III,Indian Minerals Year Book, Indian Bureau of Mines, 2013. 